\title{
Evaluating the Relationship Between Tinnitus Intensity, Noise Sensitivity, Health Anxiety and Depression in Adult Individuals with Tinnitus Complaints
}

\author{
Tinnitus Șikayeti Olan Yetișkin Bireylerde Tinnitus Șiddeti, \\ Gürültü Hassasiyeti, Sağlık Anksiyetesi ve Depresyon Arasındaki \\ ilișkinin Değerlendirilmesi
}

\author{
Esra TIKLAR' (D), Fatih GÜL ${ }^{2}$ \\ ${ }^{1}$ Ankara Yildirim Beyazit University, Institute of Health Sciences, Department of Audiology, Ankara, Turkey \\ ${ }^{2}$ Ankara Yildirim Beyazit University, Faculty of Medicine Department of Otorhinolaryngology Head and Neck Surgery, Ankara, Turkey
}

ORCID ID: Esra Tıklar 0000-0003-2807-3378, Fatih Gül 0000-0001-7992-0974

Cite this article as: Tıklar E and Gül F. Evaluating the Relationship Between Tinnitus Intensity, Noise Sensitivity, Health Anxiety and Depression in Adult Individuals with Tinnitus Complaints. Med J West Black Sea. 2021;5(2):218-225.

Corresponding Author

Esra Tiklar

E-mail

tiklaresra@gmail.com
Received

20.01.2021

Revision

25.03.2021

Accepted

08.04.2021

\begin{abstract}
Aim: Evaluating the relationship between tinnitus intensity, noise sensitivity, health anxiety and depression in adult individuals with tinnitus complaints.

Material and Methods: 190 individuals aged 19 and over and having tinnitus complaints for at least one year were included in the study. In the study, the General Information Form (GIF), Tinnitus Disability Questionnaire (TDQ), Weinstein Noise Sensitivity Scale (WNSS), Health Anxiety Inventory (HAI) and Depression Anxiety and Stress Scale Short Form (DASS-21) were used and delivered to the participants online. SPSS 22.0 was used for the statistical analyses.
\end{abstract}

Results: The mean scores of individuals with tinnitus complaint were $49.73 \pm 29.40$ for TDQ, $56.82 \pm 17.94$ for WNSS, $19.96 \pm 13.90$ for DASS-21, $18.33 \pm 9.69$ for HAI. Tinnitus intensity of $28.6 \%$ of people with noise sensitivity was very mild, $12.7 \%$ was very severe. A positive correlation was found between the total score of the TDQ and the scores of the DASS-21. A negative correlation was found between the WNSS scores and the total score of the TDQ. There was a statistically significant difference between the upper $1 / 3$, lower $1 / 3$ and middle classification values of the WNSS total scores and the TDQ classification groups. A positive correlation was found between the total score of the TDQ and the HAI and its sub-dimensions $(p<0.05)$.

Conclusion: There was a correlation between the intensity of tinnitus perceived by individuals and depression and health anxiety. A negative relationship was found in noise sensitivity with tinnitus intensity and depression. There is a positive relationship between the classification values of the noise sensitivity groups and the tinnitus intensity classification groups. Considering our findings, the intervention is thought to affect the process for tinnitus positively. Prospective controlled studies are needed to investigate the causal relationship.

Keywords: Tinnitus, Health anxiety, Noise sensitivity, Depression

öz

Amaç: Tinnitus şikayeti olan yetişkin bireylerde tinnitus şiddeti, gürültü hassasiyeti, sağlık anksiyetesi ve depresyon arasındaki ilişkinin değerlendirilmesidir. 
Gereç ve Yöntemler: Web tabanlı (online) yöntemle gerçekleştirilen araştırmaya en az bir yıldır tinnitus şikayeti olan 19 yaş ve üzeri 190 birey dahil edilmiştir. Çalışmada araştırmacı tarafından oluşturulan Genel Bilgi Formu (GBF), Tinnitus Engellilik Anketi (TEA), Weinstein Gürültü Hassasiyet Ölçeği (WGHÖ), Sağlık Anksiyetesi Envanteri (SAE) ve Depresyon Anksiyete ve Stres Ölçeği Kısa Formu (DASS-21) kullanılmışıı. Çalışmaya katılımda gönüllülük kriteri esas alınmıştır. İstatistiksel yöntem olarak çalışmada elde edilen veriler SPSS 22.0 ile analiz edilmiştir.

Bulgular: Tinnitus yakınması olan bireylerin TEA ortalama skoru 49,73 $\pm 29,40$, WGHÖ ortalama skoru 56,82 $\pm 17,94$, DASS-21 ortalama skoru 19,96 $\pm 13,90$ ve SAE ortalama skoru 18,33 \pm 9,69'dur. Gürültü hassasiyeti olan kişilerin \%28,6'sının ( $n=18$ ) tinnitus şiddeti çok hafif seviyesinde, \%12,7'sinin $(n=8)$ çok şiddetli seviyesindedir. TEA toplam puanı ile DASS-21 puanları arasında pozitif korelasyon bulunmuştur. WGHÖ puanları ile TEA toplam puanı arasında negatif yönde bir korelasyon saptanmıştır. WGHÖ toplam puanlarının üst 1/3, alt 1/3 ve orta sınılama değerleri ile TEA sınılama grupları arasında istatistiksel olarak anlamlı bir fark vardır. TEA toplam puanı ile SAE ve alt boyutları arasında pozitif korelasyon bulunmuştur $(p<0,05)$.

Sonuç: Bireylerin algıladığı tinnitus şiddeti ile depresyon ve sağılk anksiyetesi arasında pozitif ilişki bulunmuştur. Gürültü hassasiyeti ile tinnitus şiddeti ve depresyon arasında negatif ilişki saptanmıştır. Gürültü hassasiyeti gruplarının sınıflama değerleri ile tinnitus şiddeti sınıflama grupları arasında pozitif ilişki gözlenmektedir. Çalışma bulgularımızın göz önünde bulundurulmasının tinnitusa yönelik müdahale sürecini olumlu yönde etkileyeceği düşünülmektedir. Nedensellik ilişkisinin araştırılabilmesi için prospektif kontrollü çalışmalara intiyaç duyulmaktadır.

Anahtar Sözcükler: Tinnitus, Sağlık anksiyetesi, Gürültü hassasiyeti, Depresyon

\section{INTRODUCTION}

Tinnitus is a common symptom with a perception of hearing in different ways, such as ringing, buzzing, rustling, wind noise, without an external source of sound. Most studies show that the prevalence of tinnitus in adults is $10-15 \%$ (1-4).

It has been found in various studies that tinnitus meets the criteria of psychiatric diagnoses such as depression and anxiety $(5,6)$. In the literature, it is seen that the prevalence of tinnitus and depression together goes up to $30 \%(7,8)$. Anxiety is also closely related to tinnitus and can be seen in up to $45 \%$ of patients with tinnitus (5), and tinnitus is observed in about $50 \%$ of those who receive psychological treatment (9).

Health anxiety involves intense concern about a person's health and has an impact on both physical and psychological health (10). It is thought that patients with high levels of tinnitus may exhibit increased health anxiety or abnormal health behavior (11). In her study, Iwata (1984) reported that the individuals being sensitive to noise are more likely to have symptoms of inadequacy, depression, anxiety, anger, sensitivity, and tension, compared to the individuals having no noise sensitivity (12). Considering that personality structure and character traits are among the dimensions that determine the exposure level of individuals to tinnitus (13), it is seen to be important to examine the relationship between the predictors of tinnitus severity and noise sensitivity, which is a personality trait, in the adult patients with tinnitus complaints.

It is observed that the studies investigating noise sensitivity in the patients with tinnitus complaints are very limited. In addition, there are scarcely any studies in the literature addressing the relationship between tinnitus and health anxiety.
The aim of this study is to evaluate the relationship between tinnitus severity and the patient's perceived noise sensitivity, health anxiety, and depression levels.

\section{MATERIALS and METHODS}

\section{Participants}

190 individuals aged 19 and over were included in the study and the data are collected using the web-based (online) method, where the questionnaires are created using Google Forms.

Inclusion criteria for the study were; (i) having a complaint of subjective idiopathic tinnitus for a year or more in at least one ear, (ii) not having any noise exposure, (iii) being cognitively eligible to participate in the online questionnaire and (iv) being volunteer to participate in the study.

The following were excluded in the following: (i) those who have anatomical problems or diseases related to the outer ear or middle ear, (ii) those who use ototoxic drugs, have a history of ear surgery or head trauma, have a vestibular or neurological disease, have a history of chronic otitis media, Meniere's disease, have a history of acoustic tumor, neuropsychiatric disease, (iii) patients with orthopedic disease, and those using hearing aids for more than one year were not included in the study.

314 people with idiopathic tinnitus have participated in the web-based research, and 124 people were not evaluated according to the inclusion and exclusion criteria.

Tinnitus Disability Questionnaire (TDQ), Weinstein Noise Sensitivity Scale (WNSS), Health Anxiety Inventory (HAI) and Depression Anxiety and Stress Scale (DASS-21) Short Form were administered to all individuals suffering from idiopathic tinnitus. Ethics committee approval was obtained for the study. 


\section{Data Collection Tools}

\section{General information form}

It is a form that enables the sociodemographic characteristics of individuals with tinnitus complaints and the situations regarding the exclusion criteria.

\section{Tinnitus disability questionnaire (TDQ)}

In the questionnaire, which aims to evaluate the effects of tinnitus and consists of 25 questions, "yes" is scored with "4" points, sometimes with "2" points, and no answers with "0" points. It has functional, emotional, and catastrophic subscores. The total score is $100(14,15)$.

\section{Weinstein noise sensitivity scale (WNSS)}

Each question of the scale was used to determine whether individuals have noise sensitivity or not. This scale consists of 21 Likert-type items with "agree" and "disagree" answers, scaled at levels 1 to 6 . The scores corresponding to the responses of related items are added up and the WNSS score is obtained. In distinguishing the sensitivity levels of individuals to noise, the limit values of the $1 / 3$ groups with the lowest and highest scores of the sample were accepted as the cut-off point, and the cases included in these groups were considered as sensitive to noise or not sensitive to noise $(16,17)$.

\section{Health anxiety inventory (HAI)}

The scale has two sub-dimensions. Two additional separately scored subscales were included, specifically designed to measure reassurance seeking and avoidance behaviours. The first 14 items with four options in the scale constitute the hypersensitivity and anxiety dimension to somatic symptoms that question people's feelings and thoughts about their health, while the remaining 4 items constitute the negative consequences dimension of the illness, which evaluates how people will feel when they assume to have a serious illness. Each item is scored between $0-3$ ( $0=$ never, 3 = always) in the four-point rating type, and thus the score that can be obtained from the scale varies between 0 and 54 . The more the scores increase, the better health anxiety is $(18,19)$.

\section{Depression anxiety and stress scale (DASS-21) short form}

The scale is a self-report measure in which participants rate the frequency and severity of experiencing negative emotions over the previous week. Frequency/severity ratings are made on a series of 4-point scales $(0=$ did not apply to me at all, 3=applied to me very much, or most of the time) (19-21).

\section{Data Analysis}

In the descriptive statistics of the data, mean, standard deviation, median lowest, highest, frequency and ratio values were used. In the analysis of the data, the assumptions that must be met in order to decide which tests (parametric / nonparametric tests) to apply are firstly tested. In order to decide the normality of the distribution, Kolmogorov-Smirnov test was used as the other assumptions of normal distribution, kurtosis and skewness values and histogram plot. Kurtosis and skewness values are between $\pm 2.0(20)$, it is accepted that the values are normally distributed. The independent sample t-test was used for comparing two independent groups, and one-way analysis of variance (ANOVA) was used to compare more than two unrelated groups. Chisquare test was used to compare categorical variables. The relationship between the variables was examined with the Pearson correlation coefficient. The significance level of 0.05 was used as the criterion in interpreting whether the values obtained were meaningful or not. SPSS 22 program was used in the analysis.

\section{RESULTS}

Sociodemographic characteristics of 190 people participating in the research study were evaluated as frequency and percentage by frequency analysis (Table 1).

Table 1. Frequency distributions for the variables

\begin{tabular}{|c|c|c|}
\hline & Group & Cases \\
\hline & t & n (\%) \\
\hline \multirow{2}{*}{ Gender } & Male & $109(57.4)$ \\
\hline & Female & $81(42.6)$ \\
\hline \multirow{5}{*}{ Age } & $19-24$ & $14(7.4)$ \\
\hline & $25-34$ & $47(24.7)$ \\
\hline & $35-44$ & $55(28.9)$ \\
\hline & $45-54$ & $40(21.1)$ \\
\hline & 55 and over & $34(17.9)$ \\
\hline \multirow{4}{*}{$\begin{array}{l}\text { Education } \\
\text { Status }\end{array}$} & Primary and Secondary Education & $20(10.5)$ \\
\hline & High School & $46(24.2)$ \\
\hline & Undergraduate & $99(52.1)$ \\
\hline & Graduate & $25(13.2)$ \\
\hline \multirow{3}{*}{$\begin{array}{l}\text { Working } \\
\text { Status }\end{array}$} & Yes & $107(56.3)$ \\
\hline & No & $44(23.2)$ \\
\hline & Retired & $39(20.5)$ \\
\hline \multirow{3}{*}{$\begin{array}{l}\text { Buzzing/ } \\
\text { Ringing } \\
\text { Time }\end{array}$} & Only At Night & $18(9.5)$ \\
\hline & Only in Quiet Environments & $49(25.8)$ \\
\hline & Continuous & $123(64.7)$ \\
\hline \multirow{3}{*}{$\begin{array}{l}\text { Prevention } \\
\text { to Fall } \\
\text { Asleep }\end{array}$} & Often and Constantly & $38(20.0)$ \\
\hline & Sometimes & $102(53.7)$ \\
\hline & Never & $50(26.3)$ \\
\hline \multirow{4}{*}{$\begin{array}{l}\text { Humming } \\
\text { / Ringing } \\
\text { Minding } \\
\text { Status }\end{array}$} & Very Mild & $25(13.2)$ \\
\hline & Mild & $30(15.8)$ \\
\hline & Moderate & $73(38.4)$ \\
\hline & Severe & $62(32.6)$ \\
\hline \multirow{3}{*}{$\begin{array}{l}\text { High Noise } \\
\text { Exposure }\end{array}$} & Exposure for a certain period of time & $68(35.8)$ \\
\hline & No Exposure & $110(57.9)$ \\
\hline & Continuous exposure & $12(6.3)$ \\
\hline
\end{tabular}


Evaluating the Relationship Between Tinnitus Intensity, Noise Sensitivity, Health Anxiety and Depression in Adult Individuals with Tinnitus Complaints

Table 2: Summary statistics regarding the scale and sub-dimension scores

\begin{tabular}{lcc}
\hline Scale and Sub-Dimensions & $\bar{X} \pm \mathrm{S}$ & Md(min-max) \\
\hline DASS-21 Total & $19.96 \pm 13.90$ & $19.00(0.00-63.00)$ \\
\hline DASS-21 Stress & $7.29 \pm 5.04$ & $6.00(0.00-21.00)$ \\
\hline DASS-21 Anxiety & $5.81 \pm 4.64$ & $5.00(0.00-21.00)$ \\
\hline DASS-21 Depression & $6.87 \pm 5.42$ & $6.00(0.00-21.00)$ \\
\hline WNSS Total & $56.82 \pm 17.94$ & $58.00(21.00-100.00)$ \\
\hline TDQ Total & $49.73 \pm 29.40$ & $50.00(0.00-100.00)$ \\
\hline HAI Hypersensitivity to Physical Symptoms & $14.86 \pm 7.99$ & $14.00(0.00-42.00)$ \\
\hline HAI Adverse Consequences of the Disease & $3.97 \pm 2.67$ & $4.00(0.00-12,00)$ \\
\hline
\end{tabular}

DASS-21: Depression anxiety and stress scale, WNSS: Weinstein noise sensitivity scale, TDQ: Tinnitus disability questionnaire, HAI: Health anxiety inventory

Table 3: Distribution of the scale and sub-dimensions by level

\begin{tabular}{|c|c|c|}
\hline Scales & Group & Cases \\
\hline & & n (\%) \\
\hline \multirow{5}{*}{$\begin{array}{l}\text { Stress Sub-Dimension } \\
\text { Classes }\end{array}$} & Normal & $57(30.0)$ \\
\hline & Mild & 41 (21.6) \\
\hline & Moderate & 44 (23.2) \\
\hline & Severe & $20(10.5)$ \\
\hline & Very Severe & $28(14.7)$ \\
\hline \multirow{5}{*}{$\begin{array}{l}\text { Anxiety Sub-Dimension } \\
\text { Classes }\end{array}$} & Normal & 73 (38.4) \\
\hline & Mild & $12(6.3)$ \\
\hline & Moderate & 45 (23.7) \\
\hline & Severe & $19(10.0)$ \\
\hline & Very Severe & $41(21.6)$ \\
\hline \multirow{5}{*}{$\begin{array}{l}\text { Depression Sub- } \\
\text { Dimension Classes }\end{array}$} & Normal & $123(64.7)$ \\
\hline & Mild & $9(4.7)$ \\
\hline & Moderate & $26(13.7)$ \\
\hline & Severe & $22(11.6)$ \\
\hline & Very Severe & $10(5.3)$ \\
\hline \multirow{3}{*}{ WNSS Group } & Upper $1 / 3$ & 63 (33.2) \\
\hline & Middle & 64 (33.7) \\
\hline & Lower $1 / 3$ & 63 (33.2) \\
\hline \multirow{5}{*}{ TDQ Group } & Very Mild & $32(16.8)$ \\
\hline & Mild & $43(22.6)$ \\
\hline & Moderate & $32(16.8)$ \\
\hline & Severe & $40(21.1)$ \\
\hline & Very Severe & $43(22.6)$ \\
\hline
\end{tabular}

WNSS: Weinstein noise sensitivity scale, TDQ: Tinnitus disability questionnaire
The total TDQ score of individuals with tinnitus complaints was $49.73 \pm 29.40$. The DASS-21 total score was $19.96 \pm 13.90$, and the WNSS total score was $56.82 \pm 17.94$. It was observed that they got an average of $18.33 \pm 9.69$ points on the $\mathrm{HAI}$ (Table 2).

The result of classification with DASS-21 scoring table $30 \%$ of the participants $(n=57)$ are normal, $14.7 \%(n=28)$ are at a very severe stress level. While the anxiety level of $38.4 \%(n=73)$ of the participants is normal, the anxiety level of $21.6 \%(n=41)$ is very severe. While $64.7 \%(n=123)$ of them have normal depression level, $5.3 \%(n=10)$ are at very severe depression level. When the WNSS total scores were ranked from greater to lower, it was determined as 63 persons in the upper $1 / 3$ and lower $1 / 3$ groups, and 64 persons in the middle group. When the total TDQ scores are listed, it is seen that $16.8 \%(n=32)$ of the patients have very mild tinnitus, $22.6 \%(n=43)$ very severe (Table 3$)$.

DASS-21 depression sub-dimension scores showed a statistically significant difference according to the gender of the individuals $(p<0.05)$. Considering the average scores, females $(6.16 \pm 5.12)$ had higher DASS-21 depression scores than males $(6.16 \pm 5.12)$. TDQ total scores had a statistically significant difference according to the gender of the individuals $(p<0.05)$. Looking at the averages, females $(42.57 \pm 28.50)$ obtained lower TDQ scores than males $(55.05 \pm 29.06)$ (Table 4).

TDQ scores indicated a statistically significant difference according to the severity of tinnitus that prevents falling

Table 4: Findings regarding the comparison of scale and sub-dimension scores by gender

\begin{tabular}{|c|c|c|c|c|c|c|}
\hline Scale and Sub-Dimensions & & $\mathbf{n}$ & $\bar{X} \pm \mathrm{S}$ & $\mathbf{T}$ & Df & $\mathbf{p}$ \\
\hline \multirow{2}{*}{ DASS-21 Depression } & Male & 109 & $6.16 \pm 5.12$ & \multirow{2}{*}{-2.12} & \multirow{2}{*}{188} & \multirow{2}{*}{0.04} \\
\hline & Female & 81 & $7.83 \pm 5.69$ & & & \\
\hline \multirow{2}{*}{ TDQ } & Male & 109 & $55.05 \pm 29.06$ & \multirow{2}{*}{2.95} & \multirow{2}{*}{188} & \multirow{2}{*}{0.01} \\
\hline & Female & 81 & $42.57 \pm 28.50$ & & & \\
\hline
\end{tabular}

DASS-21: Depression anxiety and stress scale, TDQ: Tinnitus disability questionnaire 
asleep $(p<0.05)$. According to the Bonferroni multiple comparison test performed to observe the difference between groups, the tinnitus intensity was significantly higher in those who had frequent and constant obstacles to falling asleep caused by tinnitus, than those who sometimes had difficulties and those who could easily fall asleep (Table 5).

There is a statistically significant difference between the upper $1 / 3$, lower $1 / 3$ and middle classification values of the WNSS total scores and the TDQ classification groups, as in Table 6. The TDQ levels of $28.6 \%(n=18)$ of the individuals in the 1/3 upper group of the WNSS scale score were very mild, and $12.7 \%(n=8)$ were at the very severe level. Of the individuals in the $1 / 3$ subgroup of the WNSS scale score, $7.9 \%(n=5)$ were very mild and $33.3 \%(n=21)$ were very severe.

As can be seen in Table 7, there was a statistically significant positive correlation between DASS-21 total, anxiety and depression scores, WNSS scores and TDQ total score $(p=0.001, p<0.05)$. There was a statistically significantly positive correlation between TDQ scores and HAI Somatic Symptoms Hypersensitivity score $\left(r=0.458, r^{2}=0.210\right.$, $p<0.05)$. There was a statistically significant positive cor-

Table 5: Findings regarding to the comparison of TDQ total score and tinnitus causing to the inability to fall asleep

\begin{tabular}{|c|c|c|c|c|c|c|c|c|c|}
\hline & Group & $\mathbf{n}$ & $\bar{X} \pm S$ & Source of Varience & SS & Df & QM & $\mathbf{F}$ & $\mathbf{p}$ \\
\hline \multirow{3}{*}{ TDQ } & Frequent and Continuous ${ }^{a}$ & 38 & $61.47 \pm 26.81$ & $B-G$ & 6815.4 & 2 & 3407.72 & \multirow{3}{*}{4.07} & \multirow{3}{*}{0.02} \\
\hline & Sometimes ${ }^{b}$ & 102 & $47.71 \pm 29.93$ & W-G & 156578.3 & 187 & 837.32 & & \\
\hline & Never ${ }^{b}$ & 50 & $44.92 \pm 28.39$ & Tot. & 163393.8 & 189 & & & \\
\hline
\end{tabular}

TDQ: Tinnitus disability questionnaire, W-G: Within-group, B-G: Between-groups

* There is a significant difference between different letters

Table 6: Findings Regarding the Comparison of WNSS Groups and TDQ Scale Groups

\begin{tabular}{|c|c|c|c|c|c|c|c|}
\hline \multirow{2}{*}{\multicolumn{2}{|c|}{ WNSS Scale Group }} & \multicolumn{5}{|c|}{ TDQ Scale Group } & \\
\hline & & Very Mild & Mild & Moderate & Severe & Very Severe & \\
\hline \multirow{2}{*}{ Upper $1 / 3$} & $\mathrm{n}$ & 18 & 19 & 6 & 12 & 8 & \multirow{6}{*}{$\begin{array}{c}\text { Chi-square:20.745 } \\
\text { p:0.001 }\end{array}$} \\
\hline & $\%$ & 28.6 & 30.2 & 9.5 & 19.0 & 12.7 & \\
\hline \multirow{2}{*}{ Middle } & $\mathrm{n}$ & 9 & 14 & 12 & 15 & 14 & \\
\hline & $\%$ & 14.1 & 21.9 & 18.8 & 23.4 & 21.9 & \\
\hline \multirow{2}{*}{ Lower 1/3 } & $\mathrm{n}$ & 5 & 10 & 14 & 13 & 21 & \\
\hline & $\%$ & 7.9 & 15.9 & 22.2 & 20.6 & 33.3 & \\
\hline
\end{tabular}

WNSS: Weinstein noise sensitivity scale; TDQ: Tinnitus disability questionnaire

Table 7: Investigation of the relationship between DASS-21 scale scores, WNSS, TDQ and HAI scale scores

\begin{tabular}{|c|c|c|c|c|c|}
\hline & & TDQ & $\begin{array}{c}\text { HAl Hypersensitivity to } \\
\text { Somatic Symptoms }\end{array}$ & $\begin{array}{c}\text { HAl Adverse Consequences of } \\
\text { the Disease }\end{array}$ & HAI \\
\hline \multirow{2}{*}{ DASS-21 Total } & $r$ & 0.442 & 0.445 & 0.383 & 0.471 \\
\hline & $\mathrm{p}$ & 0.001 & 0.001 & 0.001 & 0.001 \\
\hline \multirow{2}{*}{ DASS-21 Stress } & $r$ & 0.355 & 0.406 & 0.331 & 0.426 \\
\hline & $\mathrm{p}$ & 0.001 & 0.001 & 0.001 & 0.001 \\
\hline \multirow{2}{*}{ DASS-21 Anxiety } & $r$ & 0.362 & 0.469 & 0.387 & 0.494 \\
\hline & $\mathrm{p}$ & 0.001 & 0.001 & 0.001 & 0.001 \\
\hline \multirow{2}{*}{ DASS-21 Depression } & $r$ & 0.417 & 0.361 & 0.330 & 0.389 \\
\hline & $\mathrm{p}$ & 0.001 & 0.001 & 0.001 & 0.001 \\
\hline \multirow{2}{*}{ WNSS } & $r$ & -0.222 & -0.211 & -0.201 & -0.229 \\
\hline & $\mathrm{p}$ & 0.002 & 0.004 & 0.005 & 0.001 \\
\hline \multirow{2}{*}{ TDQ Total } & $r$ & & 0.458 & 0.327 & 0.468 \\
\hline & $p$ & & 0.001 & 0.001 & 0.001 \\
\hline
\end{tabular}

DASS-21: Depression anxiety and stress scale, WNSS: Weinstein noise sensitivity scale, TDQ: Tinnitus disability questionnaire, HAI: Health anxiety inventory 
Evaluating the Relationship Between Tinnitus Intensity, Noise Sensitivity, Health Anxiety and Depression in Adult Individuals with Tinnitus Complaints

relation between TDQ scores and HAI Disease Adverse Consequences score $\left(r=0.327, r^{2}=0.107, p<0.05\right)$.

There is a statistically significant positive correlation between TDQ scores and HAI total score $\left(r=0.468, r^{2}=0.219, p<0.05\right)$ (Figure 1).

\section{DISCUSSION}

In our study, the relationship between tinnitus intensity, noise sensitivity, health anxiety and depression in individuals with tinnitus complaints was evaluated. While there are many studies in the literature that prove the relationship between anxiety, depression, and tinnitus $(6,7,22,23)$, the studies addressing the relationship between noise sensitivity (24) and health anxiety with tinnitus (11) are quite limited.

Tinnitus is a common disorder in the general population. Although much progress has been made, tinnitus is still a complex clinical symptom. Whereas many people do not feel any discomfort caused by tinnitus, most people think that this symptom changes their lives negatively (25).

It is known that many factors such as hearing loss, exposure to noise, gender, social conditions and stress are among the factors affecting tinnitus severity significantly. In a study, it was found that gender was associated with tinnitus intensity and it revealed that tinnitus intensity was higher in men than in women (26). This finding supports our research result. In another study, no significant difference was found between TDQ and gender (5).

According to the results, the tinnitus intensity of people who feel humming / tinnitus only in quiet environments was lower than those who constantly complain of humming / tinnitus. TDQ scores showed statistically significant difference in terms of prevention of falling asleep. It has been found that the severity of tinnitus was higher in people who have had sleep problems frequently or continuously. In a study, 54\% of people with tinnitus complaints had sleep disorders, and

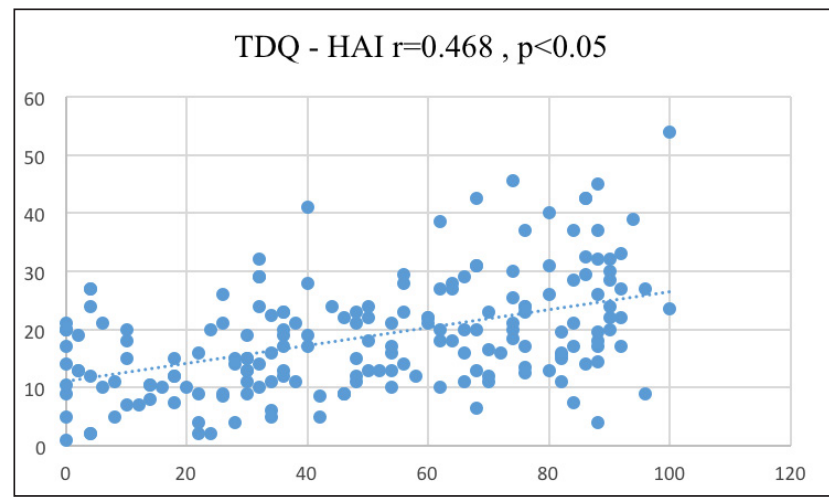

Figure 1: The Relationship Between TDQ Total Score and HAI Total Score

TDQ: Tinnitus disability questionnaire, HAI: Health anxiety inventory it was revealed that those with very severe tinnitus had difficulty in sustaining sleep (27).

In the study, a significant negative relationship was found between tinnitus intensity and noise sensitivity, and a positive relationship was found between perceived tinnitus intensity levels and noise sensitivity groups. Leaver et al. stated that the research findings support that tinnitus patients generally tend to be more sensitive to noise (26). Krog et al. reported that noise sensitivity has a significant effect on the mental and spiritual health of individuals, but it is not related to tinnitus intensity and can affect the way a person perceives tinnitus sound (28).

Taking the results into account, a significant relationship was found between the level of depression and anxiety and the severity of tinnitus. In another study, it was stated that the level of tinnitus affects depression, and the level of depression affects tinnitus (11). Sereflican et al. found a positive correlation between the degree of tinnitus disability perceived by individuals with tinnitus complaints and the severity of anxiety and depression symptoms (22).

The most important finding of our study was the positive correlation between tinnitus severity and health anxiety, between TDQ scores and HAl total score, HAl Somatic Symptoms Hypersensitivity and HAl Adverse Outcomes of Disease subscale scores. In one study, it was observed that individuals with tinnitus complaints were more preoccupied with their bodily sensations. Although physical occupation may exist as a phenomenon different from high-level health anxiety, it is not clear whether this anxiety is related to tinnitus (29). In another study, a strong relationship was found between the tinnitus and the presence of somatization disorder and hypochondriac disorder, and the frequency rates in these diagnostic subgroups were found to be $42 \%$ and $27 \%$, respectively (30).

Considering the literature and our current study, it is predicted that a treatment plan that deals with tinnitus alone without psychological evaluation will be insufficient. Studies show that effectively controlling psychological problems can also rehabilitate tinnitus symptoms. More neurobiological research is needed to develop specific treatments specific to this patient population and to elucidate the relationship between psychological problems and tinnitus $(24,31)$.

The limitations of our study are that the data were collected web-based (online) due to the COVID 19 pandemie. Also, it was a cross-sectional study. Additionally, there was no control group, and detailed evaluation interviews could not be carried out.

\section{CONCLUSION}

In this study, various degrees of relationships were found between tinnitus intensity and noise sensitivity, health anx- 
iety and depression in individuals with tinnitus complaints. Further information about the mechanism of these associations can also be obtained through prospective follow-up studies with more participants and face to face.

The clinicians treating the people with tinnitus complaints should adopt an interdisciplinary working model to provide a comprehensive treatment that addresses all aspects of this complex symptom.

\section{Acknowledgment}

None.

\section{Author Contrubitons}

Authors indicated that all contributions are equal.

\section{Conflicts of Interest}

The authors declare that they have no competing interest.

\section{Financial Support}

There are no financial supports.

\section{Ethical Approval}

This study was approved by the Ethics Committee of Ankara Yıldırım Beyazıt University (2020/299).

\section{Peer Review Process}

Extremely peer-reviewed.

\section{REFERENCES}

1. Henry JA, McMillan GP, Thielman EJ, Galvez G, Zaugg TL, Porsov E, Silaski G. Evaluating psychoacoustic measures for establishing presence of tinnitus. J Rehabil Res Dev 2013;50(4):573-584.

2. Aarhus L, Engdahl B, Tambs K, Kvestad E, Hoffman HJ. Association between childhood hearing disorders and tinnitus in adulthood. JAMA Otolaryngol Head Neck Surg 2015; 141(11):983-989.

3. Park SY, Han JJ, Hwang JH, Whang ES, Yeo SW, Park SN. Comparison of tinnitus and psychological aspects between the younger and older adult patients with tinnitus. Auris Nasus Larynx 2017;44(2):147-151.

4. Schaette R, McAlpine D. Tinnitus with a normal audiogram: Physiological evidence for hidden hearing loss and computational model. J Neurosci 2011;31(38):13452-13457.

5. Hoekstra CEL, Wesdorp FM, van Zanten GA. Sociodemographic, health, and tinnitus related variables affecting tinnitus severity. Ear Hear 2014;35(5):544-554.

6. Kuk FK, Tyler RS, Russell D, Jordan H. The psychometric properties of a tinnitus handicap questionnaire. Ear Hear 1990;11(6):434-445.

7. Bartels H, Middel BL, Van Der Laan BF, Staal MJ, Albers FWJ. The additive effect of co-occurring anxiety and depression on health status, quality of life and coping strategies in helpseeking tinnitus sufferers. Ear Hea 2008;29:947-956.
8. Salazar JW, Meisel K, Smith ER, Quiggle A, Mccoy DB, Amans MR. Depression in patients with tinnitus: A systematic review. Otolaryngol Head Neck Surg 2019;161(1):28-35.

9. Eğilmez OK, Kalcıoğlu MT, Kökten N. Questionnaire methods used in the psychosomatic evaluation of tinnitus. Kulak Burun Bogaz Ihtis Derg 2014;24(5):303-310.

10. Hogan B. Coping with health anxiety. Improving Access to Psychological Therapies (IAPT) 2010:1-24.

11. Langguth B, Landgrebe M, Kleinjung T, Sand GP, Hajak G. Tinnitus and depression. World J Biol Psychiatry 2011;12 (7):489-500.

12. Iwata $O$. The relationship of noise sensitivity to health and personality. Jpn Psychol Res 1984;26(2):75-81.

13. Langguth $B$, Kleinjung $T$, Fischer B, Hajak G, Eichhammer $P$, Sand PG. Tinnitus severity, depression, and the big five personality traits. Prog Brain Res 2007;166:221-225.

14. Newman CW, Jacobson GP, Spitzer JB. Development of the tinnitus handicap inventory. Arch Otolaryngol - Head Neck Surg 1996;122(2):143-148.

15. Aksoy S, Firat $Y$, Alpar R. The tinnitus handicap inventory: A study of validity and reliability. Int Tinnitus 2007;13:94-98.

16. Alimohammadi I, Nassiri P, Azkhosh M, Sabet M, Hosseini M. Reliability and validity of the persian translation of the weinstein noise sensitivity scale. Psychological Research 2006;9.

17. Keskin M. Comparison of the subjects with and without noise sensitivity, as determined by the Turkish version of Weinstein noise sensitivity scale following its adaptation into Turkish. M.Sc. thesis, Gazi University, Ankara, 2015.

18. Salkovskis PM, Rimes KA, Warwick HMC, Clark DM. The health anxiety inventory: Development and validation of scales for the measurement of health anxiety and hypochondriasis. Psychol Med 2002;32(5):843-853.

19. Yılmaz $\mathrm{O}, \mathrm{Boz} \mathrm{H}$, Arslan $\mathrm{A}$. The validity and reliability of depression stress and anxiety scale (Dass-21) Turkish short form. J Financ Econ Soc Res 2017;2(2):78-91.

20. Lovibond PF, Lovibond SH. The structure of negative emotional states: Comparison of the Depression Anxiety Stress Scales (DASS) with the Beck Depression and Anxiety Inventories. Behav Res Ther 1995;33(3):335-343.

21. Brown TA, Chorpita BF, Korotitsch W, Barlow DH. Psychometric properties of the Depression Anxiety Stress Scales (DASS) in clinical samples. Behav Res Ther 1997;35(1):79-89.

22. Sereflican M, Tuman TC, Çakır U, Yurttaş V. The association of perceived degree of handicap due to tinnitus and depression, anxiety symptoms in patients with tinnitus. Bozok Medical Journal 2016;1(1):51-54

23. ZogerS, Svedlund J, Holgers KM. Psychiatric disorders in tinnitus patients without severe hearing impairment: 24 month follow-up of patients at an audiological clinic. Audiology 2001;40(3):133-140.

24. McCormack A, Edmondson-Jones M, Fortnum H, Dawes PD, Middleton H, Munro KJ, Moore DR. Investigating the association between tinnitus severity and symptoms of depression and anxiety, while controlling for neuroticism, in a large middleaged UK population. Int J Audiol 2015;54(9):599-604.

25. Baguley D, McFerran D, Hall D. Tinnitus. Lancet 2013 382(9904):1600-1607. 
Evaluating the Relationship Between Tinnitus Intensity, Noise Sensitivity, Health Anxiety and Depression in Adult Individuals with Tinnitus Complaints

26. Torun MT, Kanmaz L, Tuncel Ü, Turan F, Seçkin E. The relationship between demographic and audiometric parameters and tinnitus handicap inventory in subjective tinnitus patients. Haydarpasa Numune Med J 2015;55(2):89-95.

27. Fioretti A, Fusetti M, Eibenstein A. Association between sleep disorders, hyperacusis and tinnitus: Evaluation with tinnitus questionnaires. Noise Heal 2013;15(63):91.

28. Krog NH, Engdahl B, Tambs K. The association between tinnitus and mental health in a general population sample: Results from the HUNT Study. J Psychosom Res 2010;69(3):289-298.
29. Heath I. Tinnitus and health anxiety. Br J Nurs 1994;3(10):502505.

30. Hiller W, Janca A, Burke KC. Association between tinnitus and somatoform disorders. J Psychosom Res 1997;43(6):613-624.

31. Gomaa MAM, Elmagd MHA, Elbadry MM, Kader RMA. Depression, anxiety and stress scale in patients with tinnitus and hearing loss. Eur Arch Oto-Rhino-Laryngology 2014;271(8):2177-2184. 